Radosław Kuliniak

Uniwersytet Wrocławski, Wrocław

ORCID: 0000-0002-0090-6609

e-mail: kornik90@poczta.onet.pl

\title{
Kazimierza Twardowskiego „Streszczenie” habilitacji Ingardena
}

Niniejsze rozważania wstępne dotyczą słabo znanego w literaturze przedmiotu wątku we lwowskiej procedurze habilitacyjnej Romana Witolda Ingardena. Chodzi mianowicie o podstawę jego habilitacji. Mogła to być wydana już rozprawa bądź też jej „Streszczenie”. Panujące wówczas na Uniwersytecie Lowskim procedury awansowe dopuszczały taką możliwość, a Ingarden zamierzał z nich skorzystać. Zobaczmy, jak do tego doszło.

10 lutego 1924 roku Ingarden otrzymał ze Lwowa list od Twardowskiego. Była w nim informacja o dopuszczeniu go do postępowania habilitacyjnego przed Radą Wydziału Humanistycznego Uniwersytetu Jana Kazimierza we Lwowie ${ }^{1}$. Filozof ucieszył się, że jego propozycja, tj. złożenie „Streszczenia” z pracy habilitacyjnej, została zaakceptowana. 14 lutego 1924 roku Ingarden postanowił odpisać na list Twardowskiego. Zwracał się do niego:

1 Zob. list Kazimierza Twardowskiego do Romana Witolda Ingardena z 10 lutego 1924 roku, w: Archiwum Rodzinnym Ingardena (dalej jako ARI). Niniejszy tekst wprowadzający powstał w oparciu o rozważania prezentowane wcześniej w: Rado-

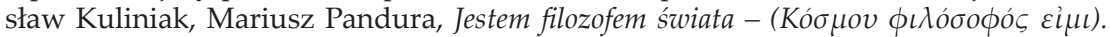
Roman Witold Ingarden (1893-1970). Część pierwsza: lata 1893-1938 (Kęty: Wydawnictwo Marek Derewiecki, 2019), 388-413 (rozdz. XXVI: „Husserl chciał, abym szybko napisał habilitację") oraz tamże, rozdz. XXVII: „Czterdzieści jeden dni wyrwanych z kalendarza", 413-423; tamże, rozdz. XXVIII: „Karuzela habilitacyjna”; tamże, 423-434; tamże, rozdz. XXIX: "Jestem zły - znów będę musiał pisać po niemiecku”, 434-448, a także rozdz. XXX: „Dzień sądu habilitacyjnego”, 448-452. 
Przede wszystkim jak najserdeczniej dziękuję Wielce Szanownemu Panu Profesorowi za zawiadomienie mnie o decyzji, jaka zapadła w sprawie mej pracy o pytaniach esencjonalnych, wzgl. w sprawie mej habilitacji zwłaszcza że decyzja ta tak dla mnie pomyślna. Zarazem gorąco dziękuję Wielce Szanownemu Panu Profesorowi za to żywe zainteresowanie się treścią mej rozprawy i za wielki nakład pracy poświęcony zapoznaniu się z nią. Umiem to tym bardziej ocenić, że zdaję sobie jasno sprawę z ilości i różnorodności zajęć, jakie ciążą na Wielce Szanownym Panu Profesorze. Jeżeli zaś objawiłem w całej tej sprawie pewną niecierpliwość i ośmieliłem się kilkakrotnie atakować Wielmożnego Pana Profesora mymi zapytaniami, to tylko dlatego, że pragnąłby już bardzo wydostać się z Torunia i pożegnać się z rozmaitymi niezbyt miłymi stosunkami. A przy tym perspektywa innej, owocniejszej, większej pracy, nadzieja, że wreszcie większość mych sił będę mógł poświęcać kształceniu młodych ludzi w filozofowaniu, że równocześnie będę miał więcej czasu na własną pracę naukową - to wszystko złożyło się na pewien stan podniecenia, który łącznie z niepewnościa, jak wypadnie decyzja Szanownego Pana Profesora, napawał mię pewną niecierpliwością. Dziś, gdy zasadnicza decyzja już zapadła, a cała sprawa stała się w znacznej mierze już tylko kwestią czasu, gdy wiem na pewno, że się z Torunia wydostanę i że nie będę całe życie uczył mnożenia wielomianów itp., sprawa odsunięcia habilitacji o kilka miesięcy jest dla mnie drugorzędnego znaczenia ${ }^{2}$.

Ingarden przystał na proponowane przez Twardowskiego ustalenia w sprawie terminu kolokwium. Nieśmiało też spytał, czy przesłane przez niego wstępne „Streszczenie” własnej habilitacji nadaje się do druku w Zeszytach Lwowskiego Towarzystwa Naukowego.

Kolejne wiadomości ze Lwowa w tej sprawie długo nie nadchodziły. Zaniepokojony tym Ingarden pod koniec lutego, dokładnie 28 lutego 1924 roku, skierował kolejne pismo do Twardowskiego ${ }^{3}$. Tym razem powiadamiał, że wyczerpał wszelkie polskie możliwości co do prób ogłoszenia swojej habilitacji na rodzimym rynku wydawniczym i liczy, że przesłane „Streszczenie” z habilitacji będzie wystarczające do kontynuacji procesu. Był trochę zażenowany, że musi po raz kolejny pisać o tym Twardowskiemu. Chciał się jednak uspokoić i ustalić wszelkie rozbieżności. Tego samego dnia dostał zresztą list od Husserla z ostateczną propozycją publikacji swojej habilitacji w VII tomie Roczników Fenomenologicznych ${ }^{4}$. Zachęcający był dla Ingardena termin jej wydania, który został określony w liście od Husserla. Była to pierwsza połowa 1925 roku.

2 Zob. list Romana Witolda Ingardena do Kazimierza Twardowskiego z 14 lutego 1924 roku, w: ARI.

${ }^{3}$ Zob. list Romana Witolda Ingardena do Kazimierza Twardowskiego z 28 lutego 1924 roku, w: ARI.

${ }_{4}$ Zob. tamże. Listy z Husserlem, o których wspomina Ingarden, nie zachowały się. W tym czasie przyszedł i zachował się list Malwiny Husserl z 24 lutego 1924 roku, w: E. Husserl, Briefe an Roman Ingarden mit Erläuterungen und Erinnerungen an Husserl, 
Filozof nie musiał więc długo czekać. Należało jedynie zasiąść do biurka, wytężyć umysł i przetłumaczyć, a jednocześnie poprawić prawie gotowy manuskrypt. Ingarden pisał o tym do Twardowskiego:

Od zeszłej soboty tłumaczę mą pracę na język niemiecki. Tekst jednak, którym rozporządzam, nie jest ostateczny, a poza tym bardzo niewyraźny i pokreślony. Uprzejmie więc proszę Wielce Szanownego Pana Profesora o przesłanie mi z powrotem tekstu maszynowego mej pracy, ponieważ on na razie i tak nie jest Szanownemu Panu Profesorowi potrzebny, a mnie znacznie ułatwi pracę. By zaś nie trudzić tą sprawą Szanownego Pana Profesora, piszę równocześnie do Kazika Ajdukiewicza z prośbą by się zajął przesyłką rękopisu ${ }^{5}$.

Ingarden ośmielił się również poprosić Twardowskiego o dopilnowanie terminu ukazania się przesłanego „Streszczenia”. Było ono konieczne do dopełnienia procesu habilitacyjnego. Filozof obawiał się, że przedłużający się termin jego wydania będzie kolidował z publikacją niemieckiego tekstu habilitacji w Rocznikach Fenomenologicznych. Co prawda czas ukazania się jego pracy po niemiecku był jeszcze dość odległy, jednak Ingarden, znając warunki polskie druku wszelkich prac, a zwłaszcza piętrzące się terminy i spóźnienia, wolał o tym wspomnieć.

Na odpowiedź czekał znów przeszło miesiąc ${ }^{6}$. Wtedy zaś Twardowski napisał, że nie może odesłać do Torunia jego maszynopisu habilitacji wraz ze „Streszczeniem”. Tłumaczył, że potrzebuje obu egzemplarzy na posiedzeniu Rady Wydziału w celu udostępnienia ich członkom komisji habilitacyjnej. Podkreślał, że bardzo był nimi zainteresowany Wartenberg. Twardowski przestrzegał przed nim Ingardena. Pisał o tym:

Z faktem, że pracę Pańską będzie jeszcze czytał Prof. Wartenberg, łączą się dla mnie pewne obawy. Po pierwsze, Prof. Wartenberg, zawsze słabowity, obecnie czuje się bardzo niedobrze i przed dwoma tygodniami wziął urlop do końca bieżącego trymestru. Nie wiem, czy stąd nie wyniknie jakaś zwłoka większa. Jest jednak jeszcze druga okoliczność, która mnie nieco niepokoi. W pewnej sprawie, wchodzącej w zakres formalnej kompetencji zarówno mojej, jak i Prof. Wartenberga, tenże zajął niedawno stanowisko przeciwne mojemu i tym sposobem sprawił, że sprawa stanęła na razie w martwym punkcie i kto wie, czy w ogóle nie przepadnie. To stanowisko Prof. Wartenberga było dla mnie zupełną niespodzianką. Przypisuję je właśnie jego stanowi zdrowia, jego daleko posuniętej neu-

hrsg. von R. Ingarden (Den Haag: Martinus Nijhoff, 1968), 27. List Husserla, o którym pisze Ingarden, pochodził z 25 lutego 1924 roku.

${ }^{5}$ Zob. list Romana Witolda Ingardena do Kazimierza Twardowskiego z 28 lutego 1924 roku, w: ARI.

6 Zob. list Kazimierza Twardowskiego do Romana Witolda Ingardena z 16 marca 1924 roku, w: ARI. 
rastenii. Nie mogę ręczyć, czy podobna niespodzianka nie spotka mnie także w sprawie Pańskiej habilitacji. Jestem naturalnie gotów przeprowadzić ją ewentualnie wbrew Profesorowi Wartenbergowi, ale sprawa może ulec opóźnieniu, jeśli Prof. Wartenberg będzie czynił jej załatwieniu po mojej myśli trudności ${ }^{7}$.

Obawy Twardowskiego okazały się płonne. Wartenberg, jak pokazały późniejsze wydarzenia, był przychylny wszelkim zamierzeniom Ingardena. Twardowski w swoim liście pisał dodatkowo o możliwościach druku „Streszczenia” pracy Ingardena w Sprawozdaniach Towarzystwa Naukowego we Lwowie. Donosit, że ukazują się one raz na cztery miesiące lub rzadziej. Oznaczało to, że z habilitacją należy uporać się jeszcze przed wakacjami. Termin czerwcowy, który Twardowski przewidywał, a później go utrzymał, nie gwarantował jednak tego, że druk „Sprawozdania" zakończy się do wakacji. Sekretarz Towarzystwa Naukowego we Lwowie, profesor Przemysław Dąbkowski, skłaniał się raczej ku drukowaniu "Streszczenia" Ingardena w czwartym, jesiennym zeszycie mającym ukazać się w 1924 roku$^{8}$. Atmosfera gęstniała. Twardowski poprosił jeszcze w swoim liście Ingardena o przesłanie stosownych pism, dokumentów i załączników habilitacyjnych. Obiecał uzupełnić całość nostryfikowanym dyplomem oraz własnym „Streszczeniem” pracy Ingardena.

Ingarden na list Twardowskiego zareagował pismem z 19 marca 1924 roku$^{9}$. Dziękował za wszelkie uwagi zawarte w liście z 16 marca 1924 roku. Zwracał Twardowskiemu uwagę na rozbieżność między terminem ukazania się „Streszczenia” a datą publikacji habilitacji w Rocznikach Fenomenologicznych. Powiadomił Twardowskiego o umowie zawartej z wydawnictwem Niemeyera. Trzy dni później napisał zaś drugi list, w którym informował o przesłaniu dokumentów habilitacyjnych wraz ze wszystkim nadbitkami własnych publikacji1" ${ }^{10}$. Donosił, że prace nad przekładem habilitacji przebiegają sprawnie. Ingarden przetłumaczył wówczas przeszło połowę swojej pracy. Był to swoisty rekord świata. Biorąc pod uwagę jego kłopoty z językiem niemieckim, który zawsze poprawiała mu panna Stein, był to wyczyn wręcz niesamowity.

Pod koniec maja 1924 roku Ingarden udał się w podróż do Lwowa. Pojechał tam dopiąc formalne sprawy habilitacyjne. Dowiózł zaległe dokumenty i złożył je w dziekanacie. Doszło też do spotkania

7 Zob. tamże.

8 Zob. tamże.

9 Zob. list Romana Witolda Ingardena do Kazimierza Twardowskiego z 19 marca 1924 roku, w: ARI.

10 Zob. list Romana Witolda Ingardena do Kazimierza Twardowskiego z 25 marca 1924 roku, w: ARI. 
z Twardowskim w słynnej kawiarni Szkockiej ${ }^{11}$, gdzie dyskutowali nad przesłanym przez Ingardena "Streszczeniem” jego pracy. Twardowski uznał już wcześniej, że „Streszczenie”, które otrzymał, nie jest dostatecznie jasne. Przedstawił własne uwagi, a dokładnie przyniósł poprawiony przez siebie tekst. Wcześniej nie mógł działać na własną rękę i wprowadzić większych zmian bez zgody autora. Dlatego też dopiero wówczas w Szkockiej czytali nowe "Streszczenie”. Zakoczyło to Ingardena. Przygotowany przez Twardowskiego tekst podobał mu się, lecz uznał go za daleko idący i odbiegający od tego, co on sam pierwotnie wyrazi1 $^{12}$. Ingarden wracał do Torunia z mieszanymi uczuciami. Był przyzwyczajony do samodzielnego pisania swoich prac, a tym bardziej koniecznych w dotychczasowych przewodach awansowych streszczeń, referatów i tym podobnych. 6 czerwca 1924 roku Ingarden napisał jeszcze Twardowskiemu, że zgadza się na to, aby w Sprawozdaniach Towarzystwa Naukowego we Lwowie zamieścić poprawione i zmienione przez niego „Streszczenie"13. Prosił także o podanie przypuszczalnego terminu druku tego tekstu. Odtąd Ingarden postanowił zgadzać na wszystko, co proponował Twardowski. Doszedł do przekonania, że gdy będzie oponował przeciw czemukolwiek, może tylko sobie zaszkodzić. Nie chciał przedłużać całego procesu. Myślał, że jego zakończenie nastąpi w najbliższym czasie, co umożliwi mu wkroczenie na nowe tory - wiodące do Lwowa. Miał dość wszelkich formalizmów ze strony Twardowskiego. Wszystko wskazywało na to, że cała sprawa będzie zmierzała do szczęśliwego finału. Rzeczywistość jednak okazała się inna.

Uspokojonego nieco Ingardena poruszył na nowo kolejny list od Twardowskiego, z 13 maja 1924 roku $^{14}$. Jakby nie było wystarczająco dużo przeszkód - pojawiły się kolejne. Tym razem Twardowski pisał, że zaszły komplikacje z drukiem koniecznego w przewodzie habilitacyjnym „Streszczenia”. Co prawda przeszło ono bez większych kłopotów na posiedzeniu Towarzystwa Naukowego we Lwowie, lecz jego druk w najbliższym czasie mógł być zagrożony. Twardowski donosił, że po poprawkach i uzupełnieniach niestety znacznie przekracza ono objętością inne streszczenia i będzie trzeba ponieść dodatkowe koszty jego publikacji. Obiecał jednak założyć pieniądze za Ingardena. Pisał, że jeśli ukażą się odbitki, zabierze je na najbliższe posiedzenie Rady Wydziału i sam przedstawi całą sprawę. Potrzebna była jedynie opinia wspierająca Wartenberga. Należało wierzyć, że ten pojawi się na Radzie i poprze

11 Potwierdza to list Romana Witolda Ingardena do Kazimierza Twardowskiego z 6 maja 1924 roku, w: ARI.

12 Zob. tamże.

13 Zob. tamże.

14 Zob. list Kazimierza Twardowskiego do Romana Witolda Ingardena z 13 maja 1924 roku, w: ARI. 
starania Ingardena. Nadzieja była nikła - nie ze względu na problemy merytoryczne, które mógł Ingardenowi wytknąć Wartenberg, lecz przede wszystkim ze względu na jego zły stan zdrowia. Dalej w swoim liście Twardowski donosił Ingardenowi o kolejnych terminach druku "Streszczenia” jego pracy. Nie miał dobrych informacji:

Co się tyczy terminu ukazania się w druku zeszytu Sprawozdań Towarzystwa ze streszczeniem Pańskiej pracy, termin ten przypadnie na jesień! Obecnie bowiem kończy się druk zeszytu obejmującego okres ostatnich czterech miesięcy roku 1923; następnie rozpocznie się druk zeszytu obejmującego pierwsze cztery miesiące roku 1924. Zeszyt zaś, obejmujący maj, czerwiec i ewentualnie lipiec oraz doroczne Walne Zgromadzenie i uroczyste doroczne posiedzenie, zacznie się drukować po ukończeniu druku zeszytu poprzedniego, więc gdzieś w lipcu lub sierpniu, a wyjdzie w druku w sierpniu lub wrześniu' ${ }^{15}$.

W tym czasie Ingarden napisał kolejny list do Twardowskiego ${ }^{16}$. Żalił się na wynikający z przepisów administracyjnych tryb zatrudniania nauczycieli w szkołach średnich w Toruniu i we Lwowie. Zasięgnął w tej sprawie opinii u wychowanka Twardowskiego - Kazimierza Sośnickiego, który pracował wówczas w Wydziale Szkolnictwa Średniego Kuratorium Okręgu Szkolnego Lwowskiego. Sprawa nie wyglądała dobrze. Nie było szans na zatrudnienie Ingardena we Lwowie. Nie zdał on ponadto egzaminu nauczycielskiego, który na terenach Galicji był wymagany. Fenomenolog prosił Twardowskiego o interwencję. Dzień później, tj. 16 maja 1924 roku, doszedł do Ingardena kolejny list od Twardowskiego - z 13 maja 1924 roku. Ingarden bardzo się nim zmartwił - dowiedział się, że dojdzie do kolizji między ukazaniem się jego "Streszczenia” a drukiem pracy. Mogło to oznaczać przesunięcie druku pracy habilitacyjnej z tomu VII do VIII Roczników Fenomenologicznych. Ingarden wziął sobie jednak do serca radę Witwickiego, który wielokrotnie powtarzał, że sprawami mającymi dopiero nastąpić nie warto się przejmować. Uznał, że nikt nie będzie sprawdzać terminu ukazania się „Streszczenia” i pracy habilitacyjnej. Jak się okazało, miał rację - „Streszczenie” planowano wydać z datą 1924 roku, a pracę habilitacyjną z datą o rok późniejszą. Ingarden powziął jedynie myśl, że w swojej pracy w Rocznikach Fenomenologicznych zamieści odpowiednią notatkę o "Streszczeniu" mającym ukazać się w Sprawozdaniach Towarzystwa Naukowego we Lwowie.

15 Zob. tamże.

16 Zob. list Romana Witolda Ingardena do Kazimierza Twardowskiego z 15 maja 1924 roku, w: ARI. 
Zanim list Ingardena doszedł do Lwowa, 17 maja 1924 roku Twardowski wysłał kolejne pismo ${ }^{17}$. Prosił w nim o krótkie streszczenia do Dązeń fenomenologów, Ueber die Gefahr einer petitio principii, Intuition und Intellekt bei Bergson, Maxa Schelera i Sporu o istote filozofii. Chciał się zabezpieczyć przed ewentualnymi pytaniami ze strony Rady Wydziału. W normalnym zaś trybie, bez mijających się listów, napisał do Ingardena 19 maja 1924 roku, odnosząc się w wiadomości do listów Ingardena z 15 i 16 maja 1924 roku $^{18}$. Zapewniał o swojej pomocy w kwestii zatrudnienia Ingardena we Lwowie. Ponadto kolejny raz obiecał służyć wsparciem w sprawie druku "Streszczenia” jego pracy habilitacyjnej.

Na podstawie dotychczas przedstawionych przez nas okoliczności widać, że karuzela habilitacyjna Ingardena w maju 1924 roku zaczęła nabierać coraz większej prędkości obrotowej. Po wymianie kolejnych listów na przełomie maja i czerwca 1924 roku można było odnieść wrażenie, że Ingarden i Twardowski wsiedli do rollercoastera, którym mknęli na przekór prawu ciążenia.

Ingarden wysłał do Twardowskiego dwa listy 26 i 27 maja 1924 roku $^{19}$. W pierwszym pisał o przeciągającym się druku "Streszczenia". Donosił, że wysłał swoją pracę habilitacyjną do Husserla z informacją o dowolnym terminie publikacji. Informował o kłopotach z uzyskaniem urlopu na przygotowanie się do kolokwium. W drugim zaś liście prosił Twardowskiego o wskazanie terminu kolokwium. Kończył też w tym czasie swój wykład habilitacyjny. Na koniec zawiadamiał, że dostał obiecany urlop z możliwością przedłużenia go do końca czerwca. W tym czasie Ingarden napisał też trzeci list do Twardowskiego. Było to 29 maja 1924 roku $^{20}$. Powiadamiał w nim, że jego praca drukuje się u wydawcy niemieckiego. Zmieniono jedynie jej tytuł z Essentionale Fragen na Essentiale Fragen ${ }^{21}$.

5 czerwca 1924 roku Twardowski stwierdził, że jego wspólne zmagania z Ingardenem powoli dobiegają końca ${ }^{22}$. Wysłał do niego list, w którym informował: „Rada Wydziału Filozoficznego Uniwersytetu Jana

17 Zob. list Kazimierza Twardowskiego do Romana Witolda Ingardena z 17 maja 1924 roku, w: ARI.

18 Zob. list Kazimierza Twardowskiego do Romana Witolda Ingardena z 19 maja 1924 roku, w: ARI.

19 Zob. listy Romana Witolda Ingardena do Kazimierza Twardowskiego z 26 maja 1924 roku oraz z 27 maja 1924 roku, w: ARI.

20 Zob. list Romana Witolda Ingardena do Kazimierza Twardowskiego z 29 maja 1924 roku, w: ARI.

${ }^{21}$ Zob. tamże.

${ }^{22}$ Zob. list Kazimierza Twardowskiego do Romana Witolda Ingardena z 5 czerwca 1924 roku, w: ARI. 
Kazimierza uchwaliła na swym wczorajszym posiedzeniu jednomyślnie dopuścić Pana Doktora do habilitacji z filozofii" ${ }^{23}$.

Na przebieg procesu habilitacyjnego Ingardena w ogromnym stopniu wpłynął Twardowski. To on stworzył, w imieniu swoim i Wartenberga, jako dwóch referentów habilitacyjnych, obszerny wniosek, w którym zdołał przekonać członków Rady Wydziału do dalszego procedowa$\mathrm{nia}^{24}$. Zawarta była $\mathrm{w}$ nim między innymi ocena dotychczasowych prac Ingardena. Pisał on w nim:

Własnych rozpraw wydał dr Ingarden drukiem dotąd pięć:

Rozprawa doktorska powyżej cytowana pt. Intuition und Intellekt bei H. Bergson. Darstellung und Versuch einer Kritik (napisana 1916/17, a drukiem ogłoszona w roku $1921 \mathrm{w}$ Jahrbuch für Philosophie und Phänomenologische Forschung, tom V, oraz w odbitce) poświęcona jest przede wszystkim systematycznemu przedstawieniu bergsonowskiej teorii poznania, przy czym problemat intuicji odgrywa rolę problematu centralnego. Przedstawianie to rozpada się na trzy części. Pierwsza część jest przedstawieniem problematyki. Wychodzi ono od opisu i przeciwstawienia dwóch różnych wyglądów przeżyć świadomości: statycznego i dynamicznego, i prowadzi do wykrycia istnienia poznania świadomości wolnego od schematów jednorodnej przestrzeni i jednorodnego czasu. Natura tego poznania - intuicji - stanowi zagadnienie centralne, którego różne strony i rolę w systemacie Bergsona omawia ta część. Druga część poświęcona jest Bergsonowskiej teorii intelektu. Rozróżnia ona trzy różne sposoby rozważania intelektu: psychologiczny, ewolucyjny i metafizyczny. Wynikiem tej części jest opracowanie schematów intelektualnych, przez które ujmujemy przy poznaniu intelektualnym rzeczywistość. Schematy te, obce zarówno rzeczywistości, którą w nie wtłaczamy, jak i bezinteresownemu poznaniu, płyną z dostosowania poznania rzeczywistości do wymogów działania jednostek psychofizycznych $\mathrm{w}$ świecie materialnym. Schematy te zniekształcają rzeczywistość i winny być przy absolutnym poznaniu eliminowane. Część trzecia omawia intuicję jako poznanie absolutne rzeczywistości, poznanie wolne od względów praktycznych i wolne wskutek tego od intelektualnych schematów. Także i w tej części osobno przedstawiono czysto psychologiczny pogląd na intuicję, a osobno pogląd ewolucyjny. Kończy się to przedstawienie teorii Bergsona przedstawieniem postulowanej przez niego metody, wynikającej z jego stanowiska. Nadto zawiera rozprawa przedwstępne rozważania krytyczne ograniczające się do krytyki immanentnej, a starające się wykazać przede wszystkim błędność Bergsonowskiego stanowiska w sprawie kategorii, które Bergson identyfikuje ze swymi schematami intelektualnymi

${ }^{23}$ Zob. tamże.

${ }^{24}$ Zob. brudnopis (pierwszy) listu Jana Ptaśnika, dziekana Wydziału Filozoficznego Uniwersytetu Jana Kazimierza do Ministerstwa Wyznań Religijnych i Oświecenia Publicznego w sprawie habilitacji dra Romana Ingardena z filozofii, Lwów, 12 lutego 1925 roku, w: DALO, f. 26, op. 5, d. 768, k. 231r. 
oraz w sprawie istoty przedmiotu. Dalsza część rozważań krytycznych wykazuje, że Bergsonowska teoria intelektu zawiera petitionem principii. W toku rozważań są także omówione warunki, jakie musi spełniać teoria poznania, jeżeli ma bez popełnienia zasadniczych błędów odpowiedzieć na swoje zasadnicze zagadnienia.

Dążenia fenomenologów jest to rozprawa ogłoszona w Przeglądzie Filozoficznym (1920), która omawia w sposób przystępny, ale samodzielny, podstawowe tendencje fenomenologii Husserla i jego uczniów. Ponieważ fenomenologia zrodziła się przede wszystkim z reakcji przeciw psychologizmowi i asocjacyjnej psychologii empirycznej, pierwszy rozdział rozprawy jest poświęcony omówieniu tendencji psychologii asocjacyjnej i jej genetycznej metody postępowania na tle metod poznania przyrodniczego. Rozdział ten określa nadto, na czym polega psychologizm, zarówno w logice, jak i w innych dziedzinach, i stara się znaleźć jego źródło. Zagadnieniom genetycznym przeciwstawia rozdział drugi dążenie fenomenologów do uzyskania wszędzie, gdzie to możliwe, bezpośredniego poznania danych naocznych i ich opisu. Omawia przy tym rolę pojęć - jako i naocznych domniemań - zarówno przy uzyskiwaniu bezpośredniego poznania, jak i przy przedstawianiu już uzyskanych w nim wyników. Rozdział trzeci przeprowadza rozgraniczenie pomiędzy bezpośrednim doświadczeniem w sensie bezpośredniego poznawania realnych przedmiotów i faktów a bezpośrednim poznaniem apriorycznym i omawia stosunki zachodzące pomiędzy obu tymi sposobami poznania. Rozdział czwarty w końcu zarysowuje tendencje Husserla w teorii poznania, a zwłaszcza sprawę tzw. epoche fenomenologicznej i poznania immanentnego przeżyć czystej świadomości. Rozprawa Über die Gefahr einer petitio principii in der Erkenntnisstheorie. Ein Beitrag zur Prinzipienfrage der Erkenntnisstheorie (Jahrbuch für Philosophie und Phänomenologische Forschung V, 1921) jest pierwszym, stanowiącym całość dla siebie, rozdziałem większej rozprawy, pozostającej dotąd w rękopisie. Zadaniem rozważań tego rozdziału jest wykazać, że jest rzeczą możliwą uniknąć w teorii poznania petitionem principii, resp. regressum ad infinitum. Jądro zarzutu skierowanego przeciw możliwości teorii poznania polega na twierdzeniu, że poznając poznanie w ogóle, musimy albo założyć na ślepo obiektywność poznania, którym się właśnie posługujemy, a tym samym i ideę poznania, i jego obiektywność w ogóle, albo też poznanie, którym się właśnie posługujemy, poddać nowemu poznaniu, które z kolei musiałoby być poznawane i tak ad infinitum. Byłoby to prawdą tylko wówczas, gdyby słusznym było założenie, iż każdy akt poznania można poznawać tylko w całkiem nowym (drugim) akcie poznania. Otóż rozprawa stara się wykazać, iż założenie to jest fałszywe i że istnieje szczególny sposób przeżywania aktów poznawczych, w którym poznajemy akty przez samo ich przeżywanie. Ten szczególny sposób przeżywania aktów świadomości - zwany przez autora intuicją - jest możliwy tylko dzięki istocie aktów świadomości, istocie, która wyróżnia świadomość od wszelkiego innego bytu. Niektóre myśli tej rozprawy, wchodzące w skład jej nieogłoszonych dotąd drukiem części, przedstawił autor na posiedzeniu sekcji metafizyczno-epistemologicznej I. Zjazdu Filozofów 
Polskich we Lwowie w roku 1923 w referacie pt. „Czy i jak można wykazać obiektywność spostrzeżenia zewnętrznego".

Artykuł pod tytułem Max Scheler (Przeglad Warszawski, 1922) podaje sylwetkę duchową Schelera na tle jego epoki i przedstawia rolę, jaką odegrał Scheler w czasie wojny w Niemczech. Zwłaszcza podkreśla na tle podstawowych dążeń Schelera w etyce i filozofii kultury przeciwstawienie się Schelera kulturze nowożytnej i zwrot jego ku średniowieczu i katolicyzmowi.

Rozprawa pod tytułem Spór o istote filozofii (Przeglad Warszawski, 1922) zwraca się zarówno przeciw popularnemu poglądowi na filozofię, w myśl którego za filozoficzne uchodzą wszelkie naukowe nieuzasadnione poglądy na świat i życie, jak też przeciw tendencjom zmierzającym do wykazania, że nie ma żadnej filozofii jako jednolitej nauki, a powołującym się na różnorodność i rozbieżność faktycznie istniejących teorii „filozoficznych". Analogiczną różnorodność znajdujemy również w matematyce, a jednak nie zrywamy z poglądem, że cała matematyka tworzy pewną zamkniętą i jednolitą całość, ponieważ pomiędzy poszczególnymi teoriami matematycznymi zachodzą pokrewieństwa dziedzin przedmiotów badanych i wzajemne zawisłości. Podobne pokrewieństwa i zawisłości można wykazać i pomiędzy poszczególnymi działami filozofii. Rozbieżność pomiędzy faktycznie istniejącymi poglądami filozoficznymi nie może służyć za argument przeciw istnieniu filozofii, bo w ogóle istnienie takich czy innych faktów, historycznie uwarunkowanych, nie może wpłynać na decyzję co do istnienia tej czy innej nauki jako jednolitego systematu wykrywanych prawd. O istnieniu takiego systematu decyduje istnienie lub nieistnienie odpowiedniej jednolitej i odrębnej dziedziny przedmiotów oraz stanów rzeczy. Istnienia takiej dziedziny - o ile chodzi o filozofię - rozprawa niniejsza nie zamierza wykazać - wskazuje tylko pokrótce, że dziedziny przedmiotów badań filozoficznych należy szukać $\mathrm{w}$ dziedzinie istot idealnych.

Praca habilitacyjna doktora Ingardena nosi tytuł O pytaniach essencjonalnych i obejmuje 176 stronic folio pisma maszynowego. Obszerne streszczenie pracy tej przedstawił prof. dr Kazimierz Twardowski Towarzystwu Naukowemu we Lwowie na posiedzeniu Wydziału Historyczno-Filozoficznego dnia 13 maja 1924 - streszczenie to się załącza. Jak wszystkie poprzednie rozprawy doktora Ingardena, tak też i jego praca habilitacyjna jest wyrazem kierunku filozoficznego zainicjowanego z początkiem wieku XX przez Edmunda Husserla, ongiś ucznia Franciszka Brentany, pod nazwą kierunku fenomenologicznego. W duchu tego kierunku, opierając się na jego zasadniczych poglądach i przestrzegając jego metody, doktor Ingarden podjął się w swej pracy habilitacyjnej opracowania kompleksu kwestii, które dotąd nie zajęły należnego miejsca w badaniach fenomenologicznych Husserla i jego szkoły, chociaż łączą się ściśle z pojęciem „istoty", odgrywającym w tych badaniach tak wybitną rolę. Toteż pomysł zajęcia się analizą pytań essencjonalnych (essencjalnych), tj. pytań, skierowanych $\mathrm{ku}$ „istocie”, trzeba nazwać bardzo szczęśliwym i to nie tylko ze stanowiska fenomenologicznego. Dwa zachodzą tu w grę rodzaje pytań: po pierwsze pytanie o formę „,co to jest?", gdzie „to" wskazuje przedmiot 
jednostkowy, a odpowiedź w postaci „to jest P” zawiera w swym orzeczeniu pojęcie ogólne, po drugie pytanie o formę „,co to jest P?”, gdzie odpowiedź dostarcza nam wiadomości bądź o najważniejszych, bądź o wszystkich elementach „,istoty” owego przedmiotu. Toteż dwa te pytania, wzięte łącznie, tworzą pytanie essencjonalne. Oto teza główna pracy habilitacyjnej. Około przygotowania, uzasadnienia i rozprowadzenia tej tezy w niektóre doniosłe jej konsekwencje obracają się rozważania Autora. Tok jego myśli porusza się do analizy „pytania” w ogóle poprzez rozróżnienie znaczeń, jakie pytania mieć moga, i celów, w jakich można je zadawać, ku różnym na pytania odpowiedziom i szczegółowemu rozbiorowi całego szeregu pojęć, wśród których pojęcia „istoty” i „idei” zajmują miejsce główne. Wyniki z tego rozbioru pozwalają Autorowi zwrócić się krytycznie przeciw konwencjonalizmowi epistemologicznemu i tym sposobem tym silniej utwierdzić jego własne stanowisko. Liczne są tedy i różnorodne zagadnienia, które doktor Ingarden w swej pracy habilitacyjnej rozważa; treścią swoją wybiega ona znacznie poza pozornie ciasne ramy, zakreślone jej tytułem. Sposób, w jaki Autor rzecz swoją przeprowadza, dowodzi niewątpliwej samodzielności. Chociaż bowiem stoi on, jak wspomniano, na gruncie fenomenologii husserlowskiej, porusza się w pracy swej na tym gruncie z całą swobodą odnosząc się krytycznie do różnych poglądów wyrażonych przez innych wyznawców kierunku fenomenologicznego. Postępuje przy tym metodycznie, ujmując krok za krokiem ostrożnie swe wywody w jasno dysponowaną całość. W wyłuszczaniu poszczególnych zagadnień i formułowaniu poszczególnych rozumowań Autor stara się o możliwie przekonujące przestawienia swoich myśli, a trudności, na które przy tym natrafia, dzięki przedmiotowi i fenomenologicznemu sposobowi traktowania go umie prawie zawsze szczęśliwie przezwyciężyć. Czytelnik, nieuznający tego sposobu i w ogóle kierunku fenomenologicznego, zauważy, że autor, będąc zwolennikiem tego kierunku, gdzieniegdzie nie liczy się dostatecznie z możliwością odmiennego ujmowania rzeczy i grożącymi stąd jego twierdzeniom zarzutami. Jest to jednak cecha niemal nieuchronna wszelkich prac pisanych w duchu pewnej szkoły, a jednostronność tę, której zupełnie uniknąć zdołają tylko naprawdę przodujący myśliciele, wynagradza poniekąd wielka zwartość i spoistość wewnętrzna, oparta na mniej lub więcej już ulubionym w łonie danej szkoły systemacie pojęć i założeń. Zresztą praca habilitacyjna doktora Ingardena, nacechowana gruntownością i sumiennością naukowa, a rozpatrująca po raz pierwszy w sposób tak szczegółowy pewien rodzaj pytań, przynosi, dzięki pomysłowości Autora, bystrym jego analizom i umiejętnemu powiązaniu rozważanych przezeń problematów także sporo takich wyników, których uznanie nie jest uwarunkowane przyjęciem zasadniczego kierunku, przez autora wyznawanego. Toteż nie ulega wątpliwości, że rzecz O pytaniach essencjonalnych stanowi istotny postęp nauki i świadczy o samodzielności naukowego myślenia Autora, tak iż uprawnia doktora Ingardena do przystąpienia do dyskusji habilitacyjnej ${ }^{25}$.

${ }^{25}$ Zob. brudnopis (drugi) listu Jana Ptaśnika, dziekana Wydziału Filozoficznego Uniwersytetu Jana Kazimierza do Ministerstwa Wyznań Religijnych i Oświecenia 
Dodajmy, że „Streszczenie" habilitacji Ingardena, które wyszło ostatecznie spod pióra Twardowskiego, ukazało się w Sprawozdaniach Towarzystwa Naukowego we Lwowie, jak zostało wcześniej zapowiedziane, w czwartym roczniku w 1924 roku.

\section{Bibliografia}

Brudnopis (drugi) listu Jana Ptaśnika, dziekana Wydziału Filozoficznego Uniwersytetu Jana Kazimierza do Ministerstwa Wyznań Religijnych i Oświecenia Publicznego w sprawie habilitacji dra Romana Ingardena z filozofii, Lwów, 12 lutego 1925 roku. W: DALO, f. 26, op. 5, d. 768, k. 233r-240r.

Brudnopis (pierwszy) listu Jana Ptaśnika, dziekana Wydziału Filozoficznego Uniwersytetu Jana Kazimierza do Ministerstwa Wyznań Religijnych i Oświecenia Publicznego w sprawie habilitacji dra Romana Ingardena z filozofii, Lwów, 12 lutego 1925 roku. W: DALO, f. 26, op. 5, d. 768, k. 225r-232r.

Husserl Edmund. 1968. Briefe an Roman Ingarden mit Erläuterungen und Erinnerungen an Husserl, hrsg. von R. Ingarden. Den Haag: Martinus Nijhoff.

Kuliniak Radosław, Pandura Mariusz. 2019. „Rozdz. XXVI. Husserl chciał, abym szybko napisał habilitację”, 388-413, „Rodz. XXVII. Czterdzieści jeden dni wyrwanych z kalendarza”, 413-423, „Rozdz. XXVIII. Karuzela habilitacyjna”, 423-434, „Rozdz. XXIX. Jestem zły - znów będę musiał pisać po niemiecku”, 434-448, „Rozdz. XXX. Dzień sądu habilitacyjne-

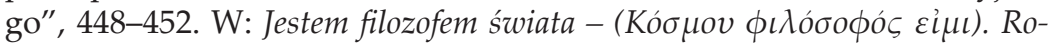
man Witold Ingarden (1893-1970). Część pierwsza: lata 1893-1938. Kęty: Wydawnictwo Marek Derewiecki.

List Kazimierza Twardowskiego do Romana Witolda Ingardena z 13 maja 1924 roku. W: ARI.

List Kazimierza Twardowskiego do Romana Witolda Ingardena z 16 marca 1924 roku. W: ARI.

List Kazimierza Twardowskiego do Romana Witolda Ingardena z 17 maja 1924 roku. W: ARI.

Publicznego w sprawie habilitacji dra Romana Ingardena z filozofii, Lwów, 12 lutego 1925 roku, w: DALO, f. 26, op. 5, d. 768, k. 233r-240r; brudnopis (pierwszy) listu Jana Ptaśnika, dziekana Wydziału Filozoficznego Uniwersytetu Jana Kazimierza do Ministerstwa Wyznań Religijnych i Oświecenia Publicznego w sprawie habilitacji dra Romana Ingardena z filozofii, Lwów, 12 lutego 1925 roku, w: DALO, f. 26, op. 5, d. 768, k. 225r-232r. Ta pierwsza wersja listu została stworzona przez referenta: Kazimierza Twardowskiego, napisana na jego maszynie do pisania, naniesione są na nią poprawki ręką Twardowskiego i na ostatniej stronie nosi notkę przez niego napisaną - „referat Twardowskiego". Data „12. II" została na maszynopis naniesiona wtórnie, odręcznie. 
List Kazimierza Twardowskiego do Romana Witolda Ingardena z 19 maja 1924 roku. W: ARI.

List Kazimierza Twardowskiego do Romana Witolda Ingardena z 5 czerwca 1924 roku. W: ARI.

List Romana Witolda Ingardena do Kazimierza Twardowskiego z 14 lutego 1924 roku. W: ARI.

List Romana Witolda Ingardena do Kazimierza Twardowskiego z 15 maja 1924 roku. W: ARI.

List Romana Witolda Ingardena do Kazimierza Twardowskiego z 19 marca 1924 roku. W: ARI.

List Romana Witolda Ingardena do Kazimierza Twardowskiego z 25 marca 1924 roku. W: ARI.

List Romana Witolda Ingardena do Kazimierza Twardowskiego z 28 lutego 1924 roku. W: ARI.

List Romana Witolda Ingardena do Kazimierza Twardowskiego z 28 lutego 1924 roku. W: ARI.

List Romana Witolda Ingardena do Kazimierza Twardowskiego z 29 maja 1924 roku. W: ARI.

List Romana Witolda Ingardena do Kazimierza Twardowskiego z 6 maja 1924 roku. W: ARI.

Listy Romana Witolda Ingardena do Kazimierza Twardowskiego z 26 maja 1924 roku oraz z 27 maja 1924 roku. W: ARI.

\section{Streszczenie}

Kłopoty Romana Witolda Ingardena z pozyskaniem habilitacji we Lwowie są powszechnie znane. Mało jednak kto zwraca uwagę na to, że konieczne do habilitowania się „Streszczenie” napisał ostatecznie Twardowski. Artykuł przedstawia perypetie z tym związane. Ważne jest jednak to, że zarówno Twardowski, jak i Ingarden dopełnili wszelkich w tym względzie formalności.

Słowa kluczowe: Roman Witold Ingarden, Kazimierz Twardowski, streszczenie do habilitacji.

\section{Summary}

Roman Witold Ingarden's problems with obtaining habilitation in Lviv are widely known. Few researchers, however, pay attention to the fact that Twardowski eventually wrote the abstract necessary for habilitation. The article presents the obstacles associated with this. It is important, however, that both Twardowski and Ingarden completed all formalities in this regard.

Keywords: Roman Witold Ingarden, Kazimierz Twardowski, abstract for habilitation. 